ORIGINAL ARTICLE, MEDICINE

\title{
Serological and Molecular Biological Studies of Parvovirus B19, Coxsackie B Viruses, and Adenoviruses as Potential Cardiotropic Viruses in Bulgaria
}

\author{
Stefka Kr. Ivanova', Svetla G. Angelova² ${ }^{2}$ Asya P. Stoyanova ${ }^{3}$, Irina L. Georgieva ${ }^{3}$, Lubomira K. \\ Nikolaeva-Glomb ${ }^{3}$, Zafira G. Mihneva' ${ }^{1}$, Neli St. Korsun ${ }^{2}$ \\ ${ }^{1}$ National Reference Laboratory of Measles, Mumps, and Rubella, NCIPD, Sofia, Bulgaria \\ ${ }^{2}$ National Reference Laboratory of Influenza and Acute Respiratory Diseases, NCIPD, Sofia, Bulgaria \\ ${ }^{3}$ National Reference Laboratory of Enteroviruses, NCIPD, Sofia, Bulgaria
}

\section{Correspondence:}

Stefka Kr. Ivanova, National Reference Laboratory of Measles, Mumps, and Rubella, NCIPD, 26 Yanko Sakazov Blvd., 1504 Sofia, Bulgaria

E-mail: stefka.krumova@gmail. com

Tel: +359878 854203

Received: 30 June 2015 Accepted: 21 June 2016 Published Online: 12 Oct 2016 Published: 23 Dec 2016

Key words: parvovirus B19, Coxsackie $B$ virus, adenoviruses, myocarditis, pericarditis, ELISA, PCR

Citation: Ivanova SK, Angelova SG, Stoyanova AP, Georgieva IL, Nikolaeva-Glomb LK, Mihneva ZG, Korsun NS. Serological and molecular biological studies of parvovirus B19, Coxsackie $B$ viruses, and adenoviruses as potential cardiotropic viruses in Bulgaria.

Folia Medica 2016:58(4):250-256 doi: 10.1515/folmed-2016-0036

\section{BACKGROUND}

Inflammatory diseases of the heart clinically manifested as inflammation of the myocardium (myocarditis) and the pericardium (pericarditis) are some
Background: Inflammatory diseases of the heart (myocarditis, pericarditis) are commonly caused by viruses. Among the human cardiotropic viruses, parvovirus B19, Coxsackie B viruses, and adenoviruses play a leading role.

Aim: The aim of the present study was to determine the presumptive causative role of parvovirus B19, Coxsackie B viruses, and adenoviruses in the development of myocarditis, pericarditis and dilated cardiomyopathy by demonstrating the presence of specific antiviral antibodies or viral DNA in patients' serum samples.

Materials and methods: We tested serum samples collected between 2010 and 2014 from 235 patients with myocarditis $(n=108)$, pericarditis $(n=79)$, myopericarditis $(n=19)$, dilated cardiomyopathy $(n=7)$, and fever of unknown origin accompanied by cardiac complaints $(n=22)$. The mean age of patients with the standard deviation was $33 \pm 18$ years. Serological and molecular methods (ELISA for specific lgM/ IgG antibodies to parvovirus B19 and IgM antibodies to Coxsackie B viruses and adenoviruses, and PCR for detection of parvovirus B19 in serum samples, respectively) were used in the study.

Results: Of all tested 235 serum samples, in 60 (25.5\%) positive results for at least one of the three tested viruses were detected. Forty out of these 235 serum samples (17\%) were Coxsackie B virus IgM positive. They were found in $17 \%(18 / 108)$ of the patients with myocarditis, in 15\% (12/79) of those with pericarditis, in $16 \%(3 / 19)$ of those with myopericarditis and in 32\% (7/22) in those with fever of unknown origin. The 63 Coxsackie B virus IgM negative patient's serum samples were tested by ELISA for presence of adenovirus IgM antibodies. Such were found in 4 patients with pericarditis and in 2 patients with fever of unknown origin. Every lgM negative sample $(n=189)$ for Coxsackie $B$ and adenovirus was further tested by ELISA for parvovirus B19 IgM/lgG antibodies. B19-IgM antibodies were detected in 14 patients (7.4\%). The percentages for B19-IgM antibodies was $8 \%(7 / 90), 5 \%(3 / 63)$ and $31 \%(4 / 13)$ in the patients affected with myocarditis, pericarditis, and fever of unknown origin, respectively. Protective B19-lgG antibodies were found in 108 (57\%) of the samples. A B19-PCR signal was detected in all the patients who were B19-IgM positive, and in only 1 patient with positive B19-IgG result, the latter presenting with dilated cardiomyopathy.

Conclusion: The present study shows the involvement of Coxsackie B, parvovirus B19 and adenoviruses in the development of inflammatory diseases of the heart (myocarditis and pericarditis). It is the first ever study in the country that simultaneously analyzes the prevalence of the three major human cardiotropic viruses. of the challenging diagnoses in cardiology and are associated largely with different types of infectious agents. ${ }^{1}$ A variety of cardiotropic viral, rickettsial, and bacterial infectious agents have been identified 
to date. ${ }^{2-4}$

The cardiotropic viruses adenovirus, enterovirus, Epstein-Barr virus, human herpes virus 6, parvovirus B19 (B19V) and cytomegalovirus, are common cough viruses. ${ }^{2,5}$ Although up to $90 \%$ of people will catch one or more of these viruses in their life without getting their heart affected, only a selected few develop clinical symptoms. ${ }^{5}$ Myocarditis is marked by inflammation and damage of the heart muscle. There are many causes of myocarditis, including viral infections, autoimmune diseases, environmental toxins, and adverse reactions to medications. The prognosis is variable but chronic heart failure is the major long term complication. Viruses are one of the most common infectious agents. They can enter cardiac myocytes and macrophages through specific receptors causing a cytotoxic effect. ${ }^{2,5}$ The infectious cause of myocarditis was originally determined in experimental and epidemiological studies in the 1950s and 1960s by investigating myocarditis patients' antibody responses to infectious agents indicating that patients had been exposed to them. These studies found that enteroviruses, including Coxsackie viruses, were present in myocarditis patients. With increasingly powerful ways to identify infectious diseases using molecular techniques in the 1980s, other viruses (including adenoviruses) were also found to be associated with myocarditis and the key role of parvovirus B19 was subsequently demonstrated..$^{2}$ The exact incidence of myocarditis remains unclear, partly due to the insensitivity of diagnostic tools used in previous studies. This may cause an underestimation of its true incidence. The prevalence of myocarditis has been found to be up to $42 \%$ in cases of unexplained deaths in people aged 35 or younger. ${ }^{6-8}$ Therefore, a certain genetic background, either or not related to immune alterations, appears to be a requisite to develop clinical symptoms of myocarditis and/or progression to dilated cardiomyopathy following virus infection in the heart.

The diagnostic gold standard is endomyocardial biopsy with the histological Dallas criteria in conjunction with the new tools of immunohistochemistry and viral $\mathrm{PCR}^{5}$, according to the 1995 WHO classification of cardiomyopathies ${ }^{9}$. Traditional serological studies, peripheral viral cultures, have been used to identify the most frequent pathogens for viral myocarditis in the past. Unfortunately, these methods lack sensitivity and specificity. ${ }^{10}$ When seroconversion (low IgG, raised IgM, and
IgA) occurs at the time of the cardiac symptoms, it may suggest viral cardiac manifestation.

The purpose of this study was to determine the presumptive causative role of three cardiotropic viruses (parvovirus B19, Coxsackie B viruses, and adenoviruses) in the development of myocarditis, pericarditis, and dilated cardiomyopathy by demonstrating the presence of specific antiviral antibodies or viral DNA in patients' serum samples.

In the present study we analyze the prevalence of the three major human cardiotropic viruses in patients who have not undergone biopsy but have presented with an inflammatory heart disease or cardiac complaints. The assays we use do not prove directly virus infection in the heart due to the high background prevalence, but can be helpful in making a presumptive diagnosis in a selected patient group who do not undergo endomyocardial biopsy for additional PCR and immunohistochemical analysis of inflammation. ${ }^{5}$

\section{MATERIALS AND METHODS}

\section{Clinical SAmples}

We tested serum samples collected between 2010 and 2014 from 235 patients with myocarditis (108), pericarditis (79), myopericarditis (19), dilated cardiomyopathy (DCM) (7), and fever of unknown origin accompanied by cardiac complaints (22). The mean age of patients with the standard deviation was $33 \pm 18$ years.

\section{LABORATORY ANALYSES}

- Serological methods - detection of specific IgM/ IgG antibodies to parvovirus B19 by commercial indirect enzyme-linked immunosorbent assay (Euroimmun, Anti-Parvovirus B19 ELISA (IgM/ $\operatorname{IgG})$ ) and $\operatorname{IgM}$ antibodies to Coxsackie B viruses (SERION ELISA classic Coxsackievirus IgM tests) and adenoviruses (Euroimmun Anti-Adenovirus ELISA (IgM) kit). The assays were performed as recommended by the manufacturer and the results were interpreted qualitatively as positive, negative or equivocal.

- Molecular methods - parvovirus B19 DNA extraction from all serum samples was performed using the PureLink ${ }^{\circledR}$ Viral RNA/DNA test kits. Screening for B19V DNA was performed with primers e1905f and e1987r $(20 \mathrm{p} / \mathrm{mol})$ located in the NS1 gene $(\mathrm{NS} 1-\mathrm{PCR})^{11}$ and KAPA Taq PCR Kits.

Forward Primer (e1905f): 5' TGCAGATGCCCTCCACCCA 3' 
Reverse Primer (e1987r): 5' GCTGCTTTCACTGAGTTCTTC 3,

CyCling Parameters of NS1-B19 PCR:

1 cycle at $94^{\circ} \mathrm{C}$ for $6 \mathrm{~min} ; 5$ cycles at $94^{\circ} \mathrm{C}$ for 30 sec, at $55^{\circ} \mathrm{C}$ for $1 \mathrm{~min}$, and at $72^{\circ} \mathrm{C}$ for $1 \mathrm{~min} ; 45$ cycles at $94^{\circ} \mathrm{C}$ for $30 \mathrm{sec}$, at $60^{\circ} \mathrm{C}$ for $30 \mathrm{sec}$, and at $72^{\circ} \mathrm{C}$ for $30 \mathrm{sec}$; final elongation at $72^{\circ} \mathrm{C}$ for 7 min. Final: hold at $4^{\circ} \mathrm{C}$.

- Electrophoresis in 2\% agarose gel to visualize the PCR products (103 bp)

\section{StaTisTICAL ANALYSIS}

All results were calculated according to proportion (percentage, \%) and evaluation of indicators of proportion including determination of the confidence interval $(95 \% \mathrm{CI})$.

\section{RESULTS}

Sixty (25.5\%) samples of patients out of all 235 samples tested positive for at least one of the three tested viruses.
Forty out of 235 serum samples $(17 \%, 95 \%$ CI $12-22 \%$ ) were Coxsackie B virus IgM positive. Positive serological results for Coxsackie B viruses were found in $17 \%(18 / 108)$ of the patients with myocarditis, in $15 \%(12 / 79)$ of those with pericarditis, in $16 \%(3 / 19)$ of those with myopericarditis, and in $32 \%(7 / 22)$ of those with fever of unknown origin (Table 1).

The serum samples of the 63 Coxsackie B virus IgM negative patients were tested for presence of adenovirus IgM antibodies (Table 2). Positive results were obtained in $6(9 \%, 95 \%$ CI $1.95-16.05), 4$ patients with pericarditis $(9 \%, 95 \%$ CI $0-18 \%)$ and in 2 patients $(40 \%, 95 \%$ CI $12-68 \%)$ with fever of unknown origin, respectively.

Every IgM negative sample $(\mathrm{n}=189)$ for Coxsackie B and adenovirus was tested by ELISA for specific parvovirus B19 IgM/IgG antibodies. B19IgM antibodies were detected in $14(7.4 \%, 95 \% \mathrm{CI}$ $3-11 \%$ ) of the samples (Table 3). The percentages of B19-IgM antibodies were $8 \%$ (7/90), 5\% (3/63),

Table 1. Number of samples tested for Coxsackie B IgM antibodies and number of positives according to diagnosis $(\mathrm{n}=235)$

\begin{tabular}{lcc}
\hline \multicolumn{1}{c}{ Diagnosis } & $\begin{array}{c}\text { Number of Coxsackie } \\
\text { ELISA IgM positives (\%) }\end{array}$ & 95\% CI \\
\hline Myocarditis $(\mathrm{n}=108)$ & $18(17 \%)$ & $10-25 \%$ \\
Pericarditis $(\mathrm{n}=79)$ & $12(15 \%)$ & $7-23 \%$ \\
Myopericarditis $(\mathrm{n}=19)$ & $3(16 \%)$ & $0-32 \%$ \\
DCM $(\mathrm{n}=7)$ & $0(0 \%)$ & $\mathrm{NA}$ \\
Fever of unknown origin accompanied by cardiac complaints & $7(32 \%)$ & $12-51 \%$ \\
$(\mathrm{n}=22)$ & $40(17 \%)$ & $12-22 \%$ \\
Total $(\mathrm{n}=235)$ & & \\
\hline
\end{tabular}

NA - not available

Table 2. Number of samples tested for adenovirus IgM antibodies and number of positives according to diagnosis $(\mathrm{n}=63)$

\begin{tabular}{|c|c|c|}
\hline Diagnosis & $\begin{array}{l}\text { Number of adenovirus } \\
\text { ELISA IgM positives }(\%)\end{array}$ & 95\% CI \\
\hline Myocarditis $(\mathrm{n}=9)$ & $0(0 \%)$ & NA \\
\hline Pericarditis $(n=41)$ & $4(9 \%)$ & $0-18 \%$ \\
\hline Myopericarditis $(\mathrm{n}=8)$ & $0(0 \%)$ & NA \\
\hline $\mathrm{DCM}(\mathrm{n}=7)$ & $0(0 \%)$ & NA \\
\hline $\begin{array}{l}\text { Fever of unknown origin accompanied by cardiac complaints } \\
(\mathrm{n}=5)\end{array}$ & $2(40 \%)$ & $12-68 \%$ \\
\hline Total $(n=63)$ & $6(9 \%)$ & $2-16 \%$ \\
\hline
\end{tabular}

NA - not available 
and $31 \%(4 / 13)$ in the patients with myocarditis, pericarditis and fever of unknown origin, respectively.

Protective B19-IgG antibodies that reveal a past parvovirus B19 infection were found in 108 $(57 \%, 95 \%$ CI $50-64 \%)$ of the samples. All positive B19-IgM and B19-IgG serum samples were tested for the presence of B19-viral DNA. A PCR signal was detected in all the patients who were B19-IgM positive, and in only 1 patient with a positive B19-IgG result, the latter presenting with dilated cardiomyopathy (Table 3).

The patients studied in this report were divided into seven age groups and the highest number were in the age groups 20-29 years $(n=46)$ and $30-39$ $(\mathrm{n}=45)$ or $39 \%(91 / 235)$ of all tested, respectively (Fig. 1).

The highest number of ELISA IgM positive samples for the three causative viral agents tested were in the age groups $20-29(25 / 46,54 \%$, Fig. 1) and $0-9(10 / 30,33 \%$, Fig. 1). They were $25 / 60$ $(42 \%)$ and $10 / 60(17 \%)$ from all IgM positive, respectively (Fig. 2). The lowest number were in the groups of patients above $40(7 / 60,12 \%$, Fig. 2).

\section{DISCUSSION}

Inflammatory diseases of the heart (myocarditis, pericarditis) are commonly caused by viruses and more than 20 of them can induce myocarditis in humans. The assays applied in the present study do not use biopsy materials for direct viral detection and do not reveal directly virus infection of the heart. They also do not cover all potential infectious causative agents of inflammatory heart disease (Epstein-Barr virus, herpes simplex virus, cytomegalovirus, Rickettsia

Table 3. Number of samples tested for B19V IgM antibodies and B19V-DNA and number of positives according to diagnosis $(\mathrm{n}=189)$

\begin{tabular}{|c|c|c|c|}
\hline Diagnosis & $\begin{array}{l}\text { Number of B19V } \\
\text { ELISA IgM positives } \\
(\%), 95 \% \text { CI }\end{array}$ & $\begin{array}{l}\text { Number of B19V } \\
\text { ELISA IgG positives } \\
\text { (\%), 95\% CI }\end{array}$ & $\begin{array}{l}\text { Number of B19V PCR } \\
\text { positives }(\%), 95 \% \text { CI }\end{array}$ \\
\hline Myocarditis $(\mathrm{n}=90)$ & $7(8 \%), 2-13 \%$ & $69(76 \%), 67-85 \%$ & $7(8 \%), 2-13 \%$ \\
\hline Pericarditis $(\mathrm{n}=63)$ & $3(5 \%), 0-10 \%$ & $30(47 \%), 35-60 \%$ & $3(5 \%), 0-10 \%$ \\
\hline Myopericarditis $(\mathrm{n}=16)$ & $0(0 \%)$, NA & $3(18 \%), 0-37 \%$ & $0(0 \%)$, NA \\
\hline $\mathrm{DCM}(\mathrm{n}=7)$ & $0(0 \%)$, NA & $2(28 \%), 0-61 \%$ & $1(14 \%), 0-40 \%$ \\
\hline $\begin{array}{l}\text { Fever of unknown origin } \\
\text { accompanied by cardiac } \\
\text { complaints }(\mathrm{n}=13)\end{array}$ & $4(31 \%), 6-56 \%$ & $4(31 \%), 6-56 \%$ & $4(31 \%), 6-56 \%$ \\
\hline Total $(\mathrm{n}=189)$ & $14(7 \%) 3-11 \%$ & $108(57 \%) 50-64 \%$ & $15(8 \%) 4-12 \%$ \\
\hline
\end{tabular}

NA - not available

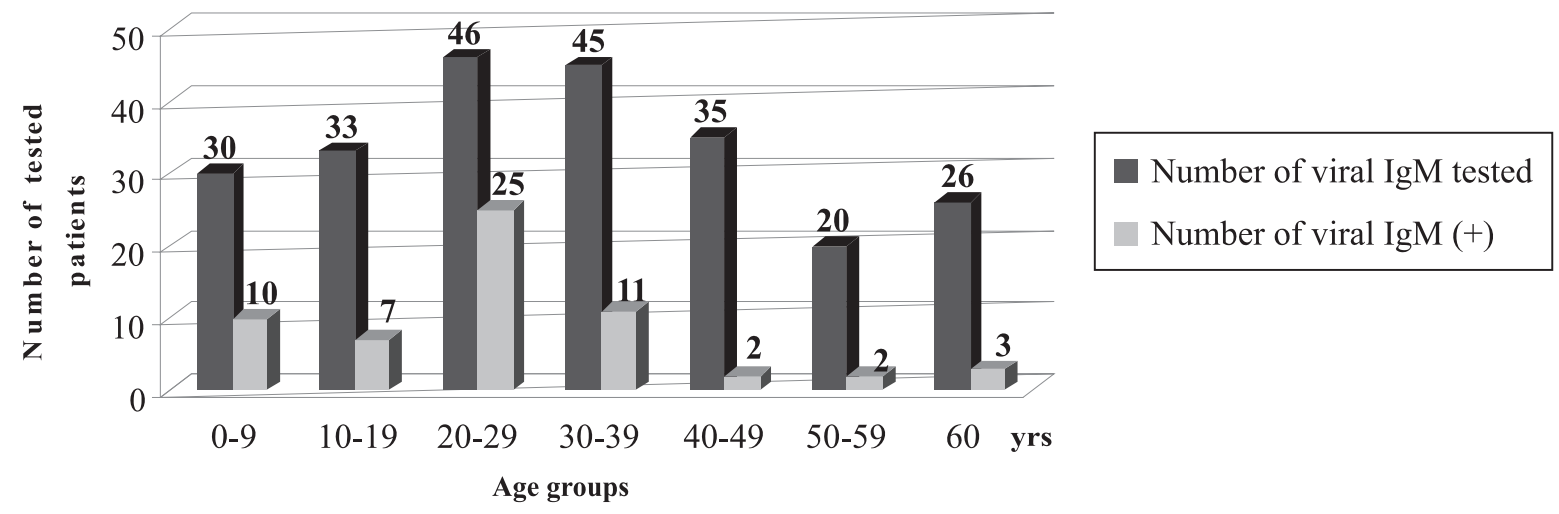

Figure 1. Number of tested patients and number of viral IgM positives according to age groups $(n=235)$. 


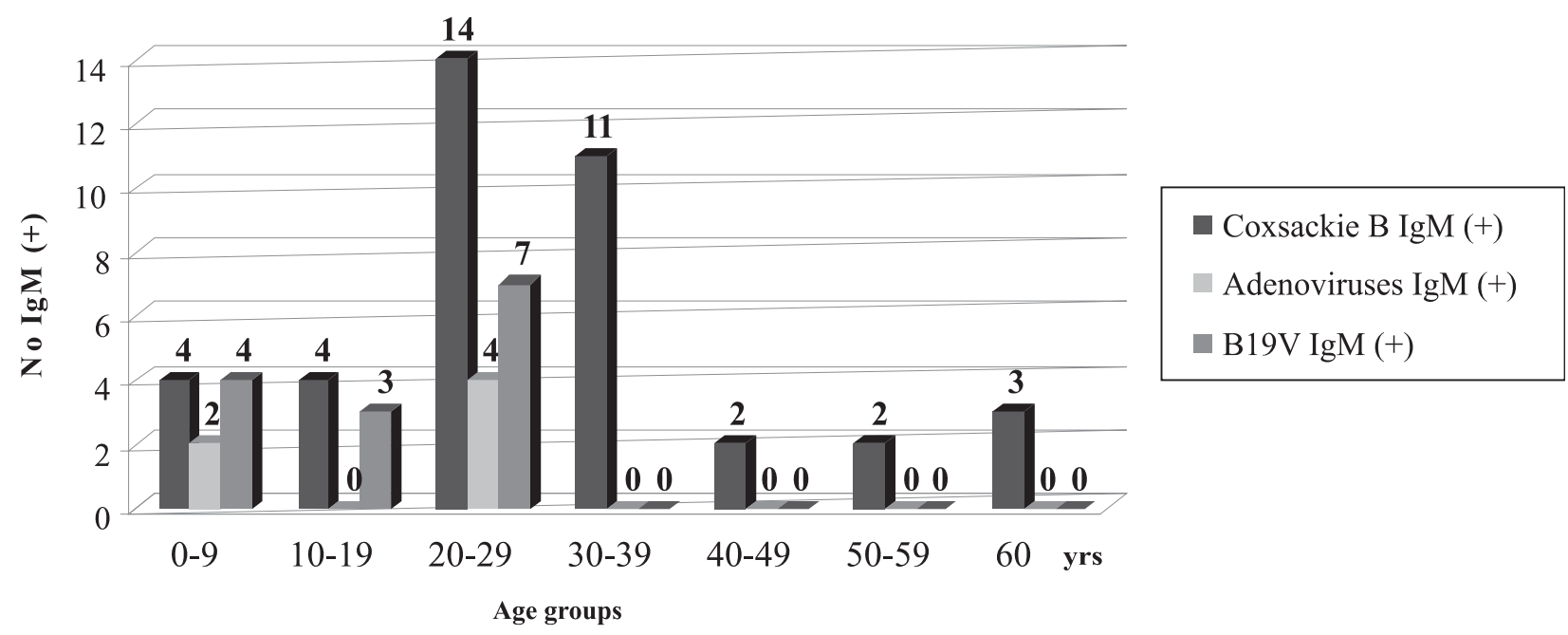

Figure 2. Number of IgM positives according to viral agents and age groups $(n=60)$.

conorii, Chlamydia, etc.). Despite these limitations of the study, the tested panel of carefully selected and analyzed samples (more than 200) over a period of five years (results described here) provides enough evidence for the leading role of parvovirus B19, Coxsackie B virus, and adenovirus infections in the pathogenesis of myocarditis and pericarditis. In the present study, $60(25.5 \%)$ patients' samples of all tested $(n=235)$ were positive for acute viral infection (Coxsackie B viruses, parvovirus B19 or adenoviruses). Positive serological IgM results for Coxsackie B viruses were found in 40/235 (17\%). These viruses are estimated to be responsible for at least $50 \%$ of the cases of infection-caused heart diseases. ${ }^{12} \mathrm{We}$ found adenovirus IgM antibodies in 6 patients, the results similar to those reported by Towbin ${ }^{13}$ concerning adenovirus participation in the development of myocarditis and pericarditis in adolescents and adults. These data are consistent with the overall frequency of viral pathogens causing inflammatory diseases of the heart ${ }^{14-16}$ which for Coxsackie B viruses and adenovirus are $20-40 \%$ and $1.6 \%$, respectively.

Many authors have reported high prevalence of $\mathrm{B} 19 \mathrm{~V}$ as a leading cardiotropic virus. ${ }^{2,17,18}$ In this regards Bowles et al. ${ }^{2}$ reported an interesting trend of the increasing number of reports on parvovirus B19 associated myocarditis and DCM and we proved acute $\mathrm{B} 19 \mathrm{~V}$ infection in $14(7 \%)$ of the tested patients mainly with diagnosis myocarditis.

Cardiac disease becomes apparent about two weeks after exposure to the virus. ${ }^{12,19}$ In adults, viral myocarditis and dilated cardiomyopathy can occur if the virus infects the heart muscle. For reasons yet unknown, the cardiac disease caused by these viruses mainly occurs in middle-aged men, with onset occurring, on average, around age $42^{19}$, and our data about the age of the affected were similar.

About the clinical diagnoses, the most affected with positive results for specific IgM antiviral antibodies were patients with myocarditis $(25 / 60$, $41.66 \%)$ and pericarditis $(19 / 60,31.66 \%)$.

\section{CONCLUSION}

The present study confirms the involvement of Coxsackie B viruses, parvovirus B19, and adenoviruses in the development of inflammatory diseases of the heart (myocarditis and pericarditis). As expected Coxsackie B viruses were with the highest frequency of proof among the tested cardiotropic viruses, namely they were found in 40 samples (17\%). This is the first study in Bulgaria to simultaneously analyze the three major human cardiotropic viruses as causative agents of inflammatory heart disease. It reveals the important role of a comprehensive etiological diagnosis of inflammatory diseases of the heart.

\section{REFERENCES}

1. Drory Y, Turetz Y, Hiss Y, et al. Sudden unexpected death in persons less than 40 years of age. Am J Cardiol 1991;68(13):1388-92.

2. Bowles NE, Vallejo J. Viral causes of cardiac inflammation. Curr Opin Cardiol 2003;18 (3):182-8.

3. Shah SS, McGowan JP. Rickettsial, ehrlichial and Bartonella infections of the myocardium and pericardium. Front Biosci 2003;8:e197-e201.

4. Wasi F, Shuter J. Primary bacterial infection of the myocardium. Front Biosci 2003;8:s228-e231.

5. Dennert R, Crijns HJ, Heymans S. Acute viral myo- 
carditis. Eur Heart J 2008;29(17):2073-82.

6. Doolan A, Langlois N, Semsarian C. Causes of sudden cardiac death in young Australians. Med J Aust 2004;180(3):110-2.

7. Basso C, Calabrese F, Corrado D, et al. Postmortem diagnosis in sudden cardiac death victims: macroscopic, microscopic and molecular findings. Cardiovasc Res 2001;50(2):290-300.

8. Maron BJ. Sudden death in young athletes. N Engl J Med 2003;349(11):1064-75.

9. Richardson P, McKenna W, Bristow M, et al. Report of the 1995 World Health Organization/International Society and Federation of Cardiology task force on the definition and classification of cardiomyopathies. Circulation 1996;93(5):841-2.

10. Baughman KL. Diagnosis of myocarditis: death of Dallas criteria. Circulation 2006;113(4):593-5.

11. Servant A, Laperche S, Lallemand F, et al. Genetic diversity within human erythroviruses: identification of three genotypes. J Virol 2002;76(18):9124-34.

12. Maze SS, Adolph RJ. Myocarditis: unresolved issues in diagnosis and treatment. Clinical Cardiology 1990;13(2):69-79.
13. Towbin JA. Myocarditis and pericarditis in adolescents. Adolesc Med 2001;12(1):47-67.

14. Calabrese F, Thiene G. Myocarditis and inflammatory cardiomyopathy: microbiological and molecular biological aspects. Cardiovasc Res 2003;60(1):11-25.

15. Kuhl U, Pauschinger M, Noutsias M, et al. High prevalence of viral genomes and multiple viral infections in the myocardium of adults with "idiopathic" left ventricular dysfunction. Circulation 2005;111(7):887-93.

16. Bowles NE, Ni J, Kearney DL, et al. Detection of viruses in myocardial tissues by polymerase chain reaction, evidence of adenovirus as a common cause of myocarditis in children and adults. J Am Coll Cardiol 2003;42(3):466-72.

17. Maisch B, Ristic AD, Portig I, et al. Human viral cardiomyopathy. Front Biposci 2003;8:s39-67.

18. Dennert R, Crijns HJ, Heyman S. Acute viral myocarditis. Eur Heart J 2008;29(17):2073-82.

19. Towbin J. Viral Myocarditis. In: Richman D, Whitley R, Hayden F, editors. Clinical Virology, Third Edition. Washington: ASM Press; 2009:97-107.

\title{
Серологические и молекулярно-биологические исследования парво- Вируса В19, коксаки В и аденовирусов в качестве потенциальных кардиотропных вирусов в Болгарии
}

\author{
Стефка Кр. Иванова ${ }^{1}$, Светла Г. Ангелова ${ }^{2}$, Ася П. Стоянова ${ }^{3}$, Ирина Л. Георгиева ${ }^{3}$, \\ Любомира Кр. Николаева-Гломб ${ }^{3}$, Зафира Г. Михнева ${ }^{1}$, Нели Ст. Корсун ${ }^{2}$ \\ ${ }^{1}$ Национальная референтная лаборатория “Корь, паротит, рубеола”, София, Болгария \\ ${ }^{2}$ Национальная референтная лаборатория “Грипп и ОР3”, София, Болгария \\ ${ }^{3}$ Национальная референтная лаборатория "Энтеровирусы", Национальный центр инфекционных и паразитарных забо- \\ леваний, София, Болгария
}

\section{Адрес для корреспонденции: Стефка Кр. Иванова, \\ Национальная референтная лаборатория “Корь, паротит, рубеола", бул. "Янко Саказов" 26, 1504 София, Болгария \\ E-mail: stefka.krumova@gmail.com Tel: +359878854203}

Дата получения: 30 июня 2015 г. Дата приемки: 21 июня 2016 г. Дата онлайн публикации: 12 октября 2016 г.

Дата публикации: 23 декабря 2016 r.

Ключевые слова: парвовирус В19, Коксаки В вирус, аденовирусы, миокардит, перикардит, ELISA, PCR
Контекст: Вирусы являются наиболее распространёнными инфекционными агентами, причиняющими воспалительные заболевания сердца (миокардит, перикардит). Среди кардиотропных вирусов ведущее место занимают парвовирус В 19, Коксаки В и аденовирусы.

Цель: Установить участие парвовируса В19, Коксаки В и аденовирусов в развитии миокардита, перикардита и дилатативной кардиомиопатии (ДКМП) путём выявления наличия специфических антивирусных антител или вирусной ДНК в сывороточных пробах пациентов.

Материалы и методы: Исследованы были 235 сывороточных проб пациентов (средний возраст со стандартным отклонением $33 \pm 18$ лет.) с миокардитом $(n=108)$, перикардитом $(n=79)$, миоперикардитом $(n=19)$, ДКМП $(n=7)$ и неясным температурным состоянием (НTC) с симптомами заболеваний сердца (n=22), заболевшими в период 2010-2014 г. Использованы были серологические (ELISA тесты на установление наличия $\mathrm{lgM} / \mathrm{lgG}$ антител в отношении парвовируса В19 и IgМ антител В отношении Коксаки В и аденовирусов) и молекулярные (PCR на установление наличия парвовируса B19 в сывороточных пробах) методы. 


\section{Образец цитирования:} Ivanova SK, Angelova SG, Stoyanova AP, Georgieva IL, NikolaevaGlomb LK, Mihneva ZG, Korsun NS. Serological and molecular biological studies of parvovirus B19, Coxsackie B viruses and adenoviruses as potential cardiotropic viruses in Bulgaria.

Folia Medica 2016;58(4):250-256 doi: 10.1515/folmed-2016-0036
Результаты: В исследованных 235 сывороточных пробах в 60 случаях (25.5\%) установлены положительные результаты наличия минимум одного из трёх вирусов. IgМ антитела в отношении Коксаки В вируситов были установлены в 40 (17\%) из исследованных 235 проб. Положительные результаты на наличие Коксаки В были установлены у 17\% (18/108) пациентов с миокардитом, 15\% (12/79) с перикардитом, 16\% (3/19) с миоперикардитом и 32\% (7/22) с НTC. 63 пробы с негативными результатами в отношении Коксаки В были исследованы с применением ELISA на установление наличия аденовирусных IgM антител. Положительные результаты были установлены у 4 пациентов с перикардитом и у 2 с НТС. Негативные в отношении Коксаки В и аденовирусов сывороточные пробы ( $\mathrm{n}=189$ ) были исследованы на установление наличия специфических парвовируса B19 lgM/lgG. В 14 (7.4\%) пробах было установлено наличие B19-IgM антител. Среди исследованных пациентов с миокардитом, перикардитом и НТС частота установленных В19-IgM составляла 8\% (7/90), 5\% (3/63) и 31\% (4/13). Защитные B19-IgG антитела, были установлены в 108 (57\%) пробах. Позитивный B19-PCR сигнал был установлен у всех пациентов с положительным B19-IgM, и у 1 пациента с ДКМП и положительным B19-IgG результатом.

Заключение: Данное исследование устанавливает участие Коксаки В, парвовируса В19 и аденовирусов в развитии воспалительных заболеваний сердца (миокардит и перикардит). Оно является первым исследованием такого рода в стране, в котором были анализированы одновременно все три ведущих кардиотропных вируса. 